\title{
A Self-Biomineralized Novel Adenovirus Vectored COVID-19 Vaccine for Boosting Immunization of Mice
}

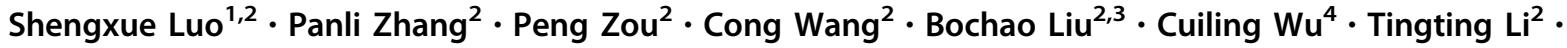 \\ Ling Zhang ${ }^{2}$ (i) $\cdot$ Yuming Zhang ${ }^{1}$ (i) $\cdot$ Chengyao $\mathrm{Li}^{2}$ (i)
}

Received: 8 May 2021 / Accepted: 28 June 2021 / Published online: 28 September 2021

(C) Wuhan Institute of Virology, CAS 2021

\begin{abstract}
SARS-CoV-2 has caused more than 3.8 million deaths worldwide, and several types of COVID-19 vaccines are urgently approved for use, including adenovirus vectored vaccines. However, the thermal instability and pre-existing immunity have limited its wide applications. To circumvent these obstacles, we constructed a self-biomineralized adenovirus vectored COVID-19 vaccine (Sad23L-nCoV-S-CaP) by generating a calcium phosphate mineral exterior (CaP) based on Sad23L vector carrying the full-length gene of SARS-CoV-2 spike protein (S) under physiological condition. This Sad23L-nCoV$\mathrm{S}-\mathrm{CaP}$ vaccine was examined for its characteristics of structure, thermostability, immunogenicity and avoiding the problem of preexisting immunity. In thermostability test, Sad23L-nCoV-S-CaP could be stored at $4{ }^{\circ} \mathrm{C}$ for over 45 days, $26{ }^{\circ} \mathrm{C}$ for more than 8 days and $37{ }^{\circ} \mathrm{C}$ for approximately 2 days. Furthermore, Sad23L-nCoV-S-CaP induced higher level of $\mathrm{S}$-specific antibody and $\mathrm{T}$ cell responses, and was not affected by the pre-existing anti-Sad23L immunity, suggesting it could be used as boosting immunization on Sad23L-nCoV-S priming vaccination. The boosting with Sad23L-nCoV-S-CaP vaccine induced high titers of $10^{5.01}$ anti-S1, $10^{4.77}$ anti-S2 binding antibody, $10^{3.04}$ pseudovirus neutralizing antibody $\left(\mathrm{IC}_{50}\right)$, and robust T-cell response of IFN- $\gamma\left(1466.16 \mathrm{SFCs} / 10^{6}\right.$ cells) to $\mathrm{S}$ peptides, respectively. In summary, the selfbiomineralization of the COVID-19 vaccine Sad23L-nCoV-S-CaP improved vaccine efficacy, which could be used in prime-boost regimen for prevention of SARS-CoV-2 infection in humans.
\end{abstract}

Keywords COVID-19 vaccine $\cdot$ Novel simian adenovirus vector $\cdot$ Self-biomineralized vaccine $\cdot$ Immunogenicity

Shengxue Luo and Panli Zhang authors contributed equally to this work.

Supplementary Information The online version contains supplementary material available at https://doi.org/10.1007/s12250021-00434-3.

\section{Chengyao Li}

chengyaoli@hotmail.com

$\triangle$ Yuming Zhang

yumingzhang1966@hotmail.com

$\triangle$ Ling Zhang

zhangling1982@163.com

1 Department of Pediatrics, Shenzhen Hospital, Southern Medical University, Shenzhen 518101, China

2 Department of Transfusion Medicine, School of Laboratory Medicine and Biotechnology, Southern Medical University, Guangzhou 510515, China

\section{Introduction}

The coronavirus disease 2019 (COVID-19) usually presents as severe acute respiratory syndrome caused by severe acute respiratory syndrome coronavirus 2 (SARSCoV-2) (Lu et al. 2020; Wang et al. 2020a), which has

3 Guangzhou Bai Rui Kang (BRK) Biological Science and Technology Limited Company, Guangzhou 510000, China

4 Department of Pediatrics, Nanfang Hospital, Southern Medical University, Guangzhou 510515, China 
become worldwide pandemic and more than 3.8 million people died worldwide (14 June 2021, WHO COVID-19 report; https://covid19.who.int/). Currently the development of safe, effective and easily preserved vaccines to prevent SARS-CoV-2 infection is urgently needed. SARS$\mathrm{CoV}-2$ genome encodes four major structural proteins, including spike (S), envelope (E), membrane (M) and nucleocapsid (N) (Srinivasan et al. 2020; Walls et al. 2020). The $S$ protein is a glycoprotein which contains $S 1$ and $\mathrm{S} 2$ subunits, and is a major protective antigen that may elicit potent neutralizing antibody (NAb) and cellular immunity. The receptor-binding domain (RBD) within S1 binds to the human angiotensin-converting enzyme 2 (hACE2) for viral entry into human cell (Srinivasan et al. 2020; Walls et al. 2020). Therefore, S antigen has been used as the primary antigen to develop candidate vaccines.

According to the World Health Organization (WHO) report of a draft landscape of COVID-19 candidate vaccines (15 June 2021, WHO COVID-19 report), some vaccines have been approved and registered for emerging use including adenovirus vector vaccine. Recombinant adenovirus vectors can induce strong immune responses and present good safety, and are widely used for research and development of vaccines (Abbink et al. 2015). According to previously published data of Ad5, ChAdOx1 and Ad26 COVID-19 vaccines (Doremalen et al. 2020; Folegatti et al. 2020; Graham et al. 2020; Mercado et al. 2020; Tostanoski et al. 2020; Zhu et al. 2020a, b), the relatively weaker immune response was found in humans with preexisting immunity or induced by a single-shot vaccine in comparison with prime-boost immunizations by two or three doses of inactivated virus or mRNA vaccines (Corbett et al. 2020; Gao et al. 2020; Jackson et al. 2020; Mulligan et al. 2020; Wang et al. 2020b). Therefore, the major limitations for wide application of adenovirus vectors are the preexisting anti-vector immunity in prime and boost immunizations, as well as the thermal instability that leads to incomplete immunization and loss of efficacy during storage and delivery of vaccines.

The novel adenoviral vector Sad23L was constructed by simian adenovirus type 23 (SAdV23), which was lowseroprevalence $(<10 \%)$ comparing with high pre-existing anti-Ad5 antibody (75.2\%) in humans (Luo et al. 2019, 2021). In addition, the calcium phosphate (CaP), as the major component of bones and teeth, is the excellent bioinorganic material and was widely used for biological applications, in particular for virus surface engineering because of its non-toxicity, biocompatibility and biodegradability (Walters and Welsh 1999; Shen et al. 2004; Lin et al. 2019). More recently, some studies showed $\mathrm{CaP}$ could serve as an excellent mineral shell candidate to stabilize virus and escape from preexisting anti-vector immunity (Wang et al. 2012, 2013, 2016), as well as adjuvant with immunostimulatory features to enhance systemic immune responses in mice (Jiang et al. 2004; Dorozhkin 2013; Lin et al. 2017; Amanat and Krammer 2020).

In this study, the novel adenovirus vector Sad23L carried the full-length $S$ gene of SARS-CoV-2, which was designated as Sad23L-nCoV-S vaccine in a separate study (Luo et al. 2021). By using CaP, Sad23L-nCoV-S was selfbiomineralized, which designated as Sad23L-nCoV-S-CaP vaccine and characterized for thermostability, immunogenicity and escaping preexisting anti-Sad23L immunity in mice.

\section{Materials and Methods}

\section{Cells and Mice}

HEK-293A, HEK-293T and HEK293T-hACE2 cells were maintained in complete Dulbecco's modified Eagle's medium (DMEM, Gibco) and incubated at $37{ }^{\circ} \mathrm{C}$ in $5 \%$ $\mathrm{CO}_{2}$. Female BALB/c mice were obtained from the Animal Experimental Centre of Southern Medical University, Guangdong, China.

\section{Production of Novel Adenovirus Vectored COVID- 19 Vaccine}

Sad23L-nCoV-S vaccine strain was previously constructed with a simian adenovirus type 23 based vector Sad23L, carrying the full-length spike protein (S) gene of SARSCoV-2 (GenBank: MN908947.3) (Luo et al. 2019, 2021). Sad23L-nCoV-S vaccine was propagated from HEK-293A cells, and purified by cesium chloride density gradient centrifugation as previously described (Luo et al. 2019).

\section{The Self-Biomineralized Sad23L-nCoV-S-CaP Vaccine}

The purified $10^{9}$ PFU Sad23L-nCoV-S vaccine was incubated with $10 \mathrm{mmol} / \mathrm{L}$ calcium chloride $\left(\mathrm{CaCl}_{2}\right)$ at $4{ }^{\circ} \mathrm{C}$ for $4 \mathrm{~h}$, and then dropwise titration of sodium hydrogen phosphate under a consistent $\mathrm{pH}(\mathrm{pH}=7.6)$ at room temperature. The Sad23L-nCoV-S-CaP vaccine was recollected by centrifugation at $8000 \times g$ as described (Wang et al. 2012).

\section{Electron Microscopy}

The morphological observation of Sad23L-nCoV-S-CaP nanoparticles was conducted by Transmission Electron Microscope (TEM, JEM-1400, JEOL, Japan) directly without any stain. Briefly, Sad23L-nCoV-S-CaP particles 
were drop-cast onto TEM grids and blown away to keep dried without stain. In comparison, Sad23L-nCoV-S particles were stained with phosphotungstic acid. Energydispersive X-ray spectroscopy (EDS) analysis of Sad23LnCoV-S-CaP and Sad23L-nCoV-S was conducted using Scanning Electron Microscope (SEM, S-3000 N, Hitachi, Japan).

\section{Virus Titration and Thermal Stability Tests}

Titers of purified viruses were calculated in PFU/mL by standard plaque-forming assay on HEK-293A, in which the cells are infected with serially diluted adenovirus stock and then over laid with agar, and a plaque will form as the result of a single infectious event. Sad23L-nCoV-S and Sad23L-nCoV-S-CaP were incubated at $4{ }^{\circ} \mathrm{C}, 26{ }^{\circ} \mathrm{C}$ and $37^{\circ} \mathrm{C}$, respectively, and samples were collected periodically. The infectivity of the remainings was detected by standard plaque-forming assay on HEK-293A.

\section{Western Blotting}

HEK-293A cells were infected with Sad23L-nCoV-S or Sad23L-nCoV-S-CaP strains, respectively, and Sad23LGFP or Sad23L-GFP-CaP was used as controls. The expression of SARS-CoV-2 S protein was analyzed by Western blotting with rabbit polyclonal antibody to SARSCoV-2 RBD (Sino Biological, China). The nitrocellulose (NC) membrane was developed by Supersignal West Pico Plus chemiluminescent substrate (Thermo Scientific, USA).

\section{Dot Plot Assays}

For immunological detection of $\mathrm{Sad} 23 \mathrm{~L}$ coat proteins, the CaP, Sad23L-nCoV-S and Sad23L-nCoV-S-CaP (native and denatured) were spotted onto a nitrocellulose filter (NC) membrane, then air-dried and blocked using 5\% skim milk in PBST. The NC membrane was incubated with a polyclonal antibody anti-Sad23L, followed by an alkaline phosphatase-conjugated goat anti-mouse antibody. Signals were generated by the addition of 5-bromo-4-chloro-3-isdolyl phosphate/nitro blue tetrazolium (BCIP/NBT).

\section{Adenovirus Neutralizing Antibody Assay}

Mouse plasma samples were collected and detected for the neutralizing antibody (NAb) titer to Sad23L-GFP or Sad23L-GFP-CaP viruses in HEK-293A cells by green fluorescent activity assay as previously described. NAb titers were defined as the maximum serum dilution that neutralized $50 \%$ of green activity (Luo et al. 2019; Wang et al. 2019).

\section{Animal Immunization}

Female BALB/c mice (5-6 weeks, $\mathrm{n}=5$ /group) were individually inoculated intramuscularly (i.m.) with a dose of $10^{7}$ PFU Sad23L-nCoV-S or Sad23L-nCoV-S-CaP vaccine, respectively. A dose of $10^{7}$ PFU Sad23L-GFP virus and an equivalent volume of $\mathrm{CaP}$ were used as sham controls (Supplementary Table S1). Female BALB/c mice (5-6 weeks, $n=5$ each group) were primed by intramuscular inoculation with PBS or $10^{7}$ PFU Sad23L-GFP, and then were boosted with a dose of $10^{7}$ PFU Sad23L-nCoV-S or Sad23L-nCoV-S-CaP at 4-week interval (Supplementary Table S2). Female BALB/c mice (5-6 weeks, $\mathrm{n}=5$ /group) were intramuscularly primed with $10^{7} \mathrm{PFU}$ Sad23L-nCoV-S, and then were boosted with $10^{7} \mathrm{PFU}$ Sad23L-nCoV-S or Sad23L-nCoV-S-CaP at 4-week interval, respectively (Supplementary Table S3).

\section{Enzyme-Linked Immunosorbent Assay (ELISA)}

The plates were coated overnight with $1 \mu \mathrm{g} / \mathrm{mL}$ of recombinant S1 or S2 protein of SARS-CoV-2 (Sino Biological, China). Sera were threefold serially diluted and specific binding antibodies (BAb) were detected by ELISA. Endpoint titers were defined as the highest reciprocal serum dilution that yielded an absorbance $>0.2$, and a ratio of signal than cutoff $(\mathrm{S} / \mathrm{CO})>1 . \log 10$ end point titers were reported (Yu et al. 2020).

\section{Pseudovirus Neutralization test (pVNT)}

SARS-CoV-2 pseudoviruses expressing a luciferase reporter gene were generated for measuring of specific neutralizing antibody (NAb) titer as previously described (Yu et al. 2020). Briefly, the plasmids psPAX2 (Addgene), pLenti-CMV Puro-Luc (Addgene) and pcDNA3.1-S $\Delta$ CT were co-transfected into HEK-293T cells. The supernatants were collected $48 \mathrm{~h}$ post-transfection and purified by filtration through $0.45 \mu \mathrm{m}$ filter. The two-fold serial dilutions of heat-inactivated serum samples mixed with $50 \mu \mathrm{L}$ of pseudovirus incubated for $1 \mathrm{~h}$ at $37^{\circ} \mathrm{C}$, the mixture was added to HEK293T-hACE2 cells. After $48 \mathrm{~h}$, cells were lysed with Steady-Glo Luciferase Assay (Promega). The pVNT NAb titer to SARS-CoV-2 was defined as the reciprocal serum dilution at which a $50 \%$ inhibition rate was obtained. Inhibition rate $(\%)=(1-$ sample (Relative light units, RLU)/virus control RLU) $\times 100$. Log 10 pVNT $\left(\mathrm{IC}_{50}\right)$ titer was reported.

\section{ELISpot}

Mouse splenocytes $\left(5 \times 10^{5}\right.$ cells/well $)$ were stimulated with $\mathrm{S}$ peptides $(3 \mu \mathrm{g} / \mathrm{mL})$ in triplicates, and detected 
SARS-CoV-2 S antigen-specific T lymphocyte response by Mice IFN- $\gamma$ ELISpot kits (MabTech). SARS-CoV-2 S peptides were predicted (http://www.iedb.org/) and synthesized by Guangzhou IGE Biotechnology LTD (Supplementary Table S4). Spots were counted with a CTL Immunospot Reader (Cellular Technology Ltd). The results were expressed as spot forming cells (SFCs) per million cells.

\section{Intracellular Cytokine Staining (ICS) and Flow Cytometry}

Mouse splenocytes $\left(2 \times 10^{6}\right.$ cells/well $)$ were isolated and stimulated with $\mathrm{S}$ peptide pools ( $3 \mu \mathrm{g} / \mathrm{mL}$ each peptide), or medium as negative control. After $4 \mathrm{~h}$, the cells were incubated with Golgi Plug (BD) for $12 \mathrm{~h}$ at $37{ }^{\circ} \mathrm{C}$. Cells were collected and stained with anti-mouse CD3, CD4 and CD8 surface marker antibodies, then fixed with IC fixation buffer, permeabilized with permeabilization buffer and stained with anti-mouse interferon- $\gamma($ IFN- $\gamma)$, interleukin-2 (IL-2) and tumor necrosis factor $\alpha$ (TNF- $\alpha$ ) (eBioscience) antibodies. All samples were tested with BD FACS Canton flow cytometer (BD).

\section{Statistical Analysis}

Data are analyzed with unpaired two-tailed $t$ test, one-way ANOVA, Mann-Whitney test. Statistically significant differences are indicated with asterisks $(* P<0.05$; $* * P<0.01$ and $* * * P<0.001)$. All graphs are generated with GraphPad Prism 7 software.

\section{Results}

\section{Production and Characterization of Sad23L- nCoV-S-CaP Vaccine}

The novel adenovirus vector COVID-19 vaccine (Sad23LnCoV-S) was produced by HEK-293A cell culture (Supplementary Fig. S1). In a calcium-rich culture medium under physiological condition, the surface of Sad23LnCoV-S virus was coated with calcium phosphate $(\mathrm{CaP})$ to form a biomineral virus nanoparticle as Sad23L-nCoV-S$\mathrm{CaP}$ vaccine (Fig. 1A). The Sad23L-nCoV-S viruses were presented as typical adenovirus particles observed under transmission electron microscopy (TEM) with phosphotungstic acid negative staining (Fig. 1B). The CaP-coated layer on Sad23L-nCoV-S-CaP nanoparticles was seen by Scanning Electron Microscope (SEM) (Fig. 1C), and the mineral phase from $\mathrm{Ca}, \mathrm{P}$ or $\mathrm{O}$ ions of Sad23L-nCoV-S$\mathrm{CaP}$ vaccine was measured by the energy dispersive X-ray spectroscopy (EDS) (Fig. 1D). The biomineral structure was identified by TEM without any staining, which presented a superficial CaP circle on Sad23L-nCoV-S-CaP viral particle (Fig. 1E), while generally, a native virus could not be observed by TEM without staining. By using anti-Sad23L serum in a dot blot assay, the viral surface protein was detected on both native and denatured Sad23LnCoV-S, but not from native Sad23L-nCoV-S-CaP (Fig. 1F), indicating that $\mathrm{CaP}$ blocked the binding of antibody to surface protein of Sad23L-nCoV-S virus. Expression of SARS-CoV-2 $\mathrm{S}$ protein was identified in Sad23L-nCoV-S or Sad23L-nCoV-S-CaP vaccines infected HEK-293A cells by Western blot with rabbit polyclonal antibodies specific to RBD, but not in the vector controls of Sad23L-GFP or Sad23L-GFP-CaP viruses infected cells (Fig. 1G). The infectivity of Sad23L-nCoV-S-CaP vaccine to HEK-293A cells was also tested. Cytopathic effect was observed after $48 \mathrm{~h}$ post infection, which is consistent with Sad23L-nCoV-S (Fig. 1H).

\section{Sad23L-nCoV-S-CaP Vaccine Acquired Thermostability}

The thermostability of Sad23L-nCoV-S-CaP and Sad23LnCoV-S vaccines was examined at $4{ }^{\circ} \mathrm{C}$ (cold chain), $26{ }^{\circ} \mathrm{C}$ (room temperature) and $37^{\circ} \mathrm{C}$ (high temperature) by measuring the infectious titers of vaccine with plaque assays (Fig. 2). The infectious titers of Sad23L-nCoV-S-CaP and Sad23L-nCoV-S vaccines were appeared different at three temperatures with prolonging incubation, in which the initial titer of Sad23L-nCoV-S-CaP vaccine (10 $\left.{ }^{7.98} \mathrm{PFU}\right)$ was slowly decreased to $10^{7.03} \mathrm{PFU}$ in $20 \mathrm{~d}$ at $4^{\circ} \mathrm{C}$ (Fig. 2A), to $10^{4.63} \mathrm{PFU}$ in $14 \mathrm{~d}$ at $26^{\circ} \mathrm{C}$ (Fig. 2B) or $10^{4.58} \mathrm{PFU}$ in $144 \mathrm{~h}$ at $37{ }^{\circ} \mathrm{C}$ (Fig. 2C), while the initial titer of Sad23L-nCoV-S vaccine $\left(10^{8.23} \mathrm{PFU}\right)$ was quickly decreased to $10^{5.93} \mathrm{PFU}$ in $20 \mathrm{~d}$ at $4{ }^{\circ} \mathrm{C}, 10^{1.69} \mathrm{PFU}$ in $14 \mathrm{~d}$ at $26^{\circ} \mathrm{C}$ or $10^{1.27} \mathrm{PFU}$ in $144 \mathrm{~h}$ at $37{ }^{\circ} \mathrm{C}$, respectively. At $2-\log _{10}$ reduction of the initial titer after $17.2 \mathrm{~d}, 3.2 \mathrm{~d}$ and $26.5 \mathrm{~h}$ of Sad23L-nCoV-S at $4{ }^{\circ} \mathrm{C}, 26{ }^{\circ} \mathrm{C}$ and $37{ }^{\circ} \mathrm{C}$, respectively (Fig. 2), but after 45.8 $\mathrm{d}, 8.4 \mathrm{~d}$ and $68.6 \mathrm{~h}$ of Sad23L-nCoV-S-CaP at $4{ }^{\circ} \mathrm{C}, 26{ }^{\circ} \mathrm{C}$ and $37{ }^{\circ} \mathrm{C}$. Therefore, Sad23L-nCoV-S-CaP exhibited a significantly slower inactivation rate $\left(0.0408 \mathrm{~d}^{-1}, 0.2372\right.$ $\mathrm{d}^{-1}, 0.02256 \mathrm{~h}^{-1}$ ) and its storage could be prolonged to more than $45 \mathrm{~d}$ at $4{ }^{\circ} \mathrm{C}, 8 \mathrm{~d}$ at $26{ }^{\circ} \mathrm{C}$ and $68 \mathrm{~h}$ at $37{ }^{\circ} \mathrm{C}$, respectively (Fig. 2). These results suggested that $\mathrm{CaP}$ biomineralization obviously improved Sad23L-nCoV-S-CaP vaccine thermostability, especially its infectious titer retained over $10^{6.07}$ PFU for 8 days at room temperature.

\section{Sad23L-nCoV-S-CaP Vaccine Retained Immunogenicity}

To evaluate the immunogenicity, $\mathrm{BALB} / \mathrm{c}$ mice were intramuscularly injected with a single dose of $10^{7} \mathrm{PFU}$ 
A

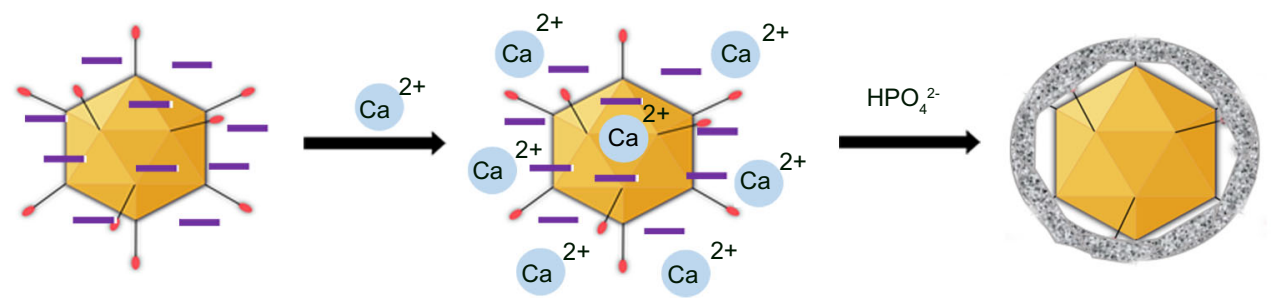

B

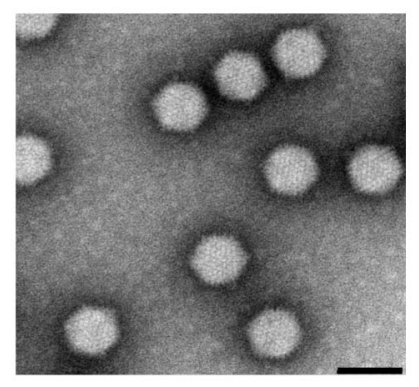

E

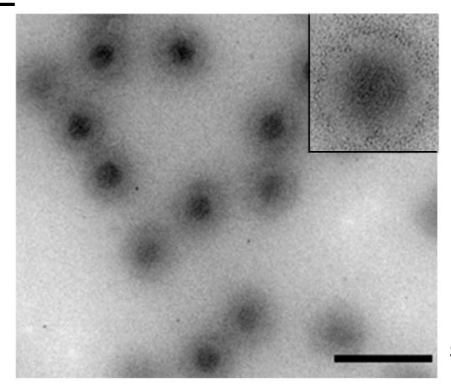

$\mathrm{H}$

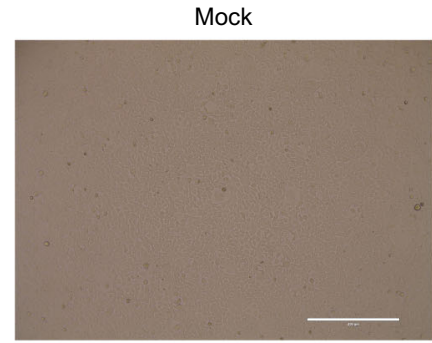

C

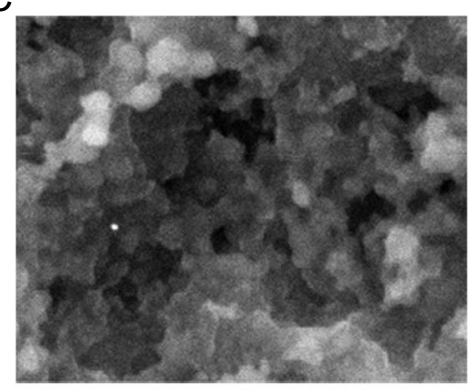

$\mathrm{F}$

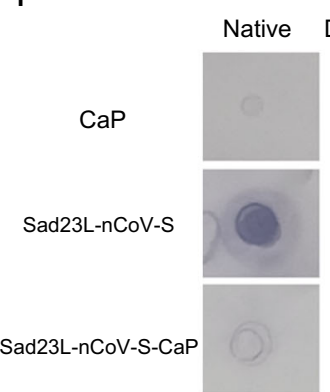

Sad23L-nCoV-S

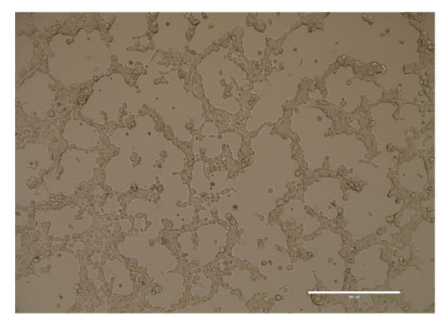

$\mathrm{D}$

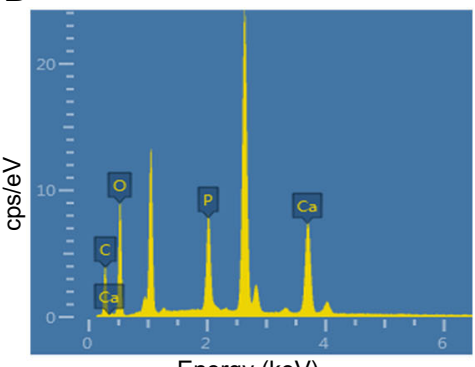

Energy (keV)

G

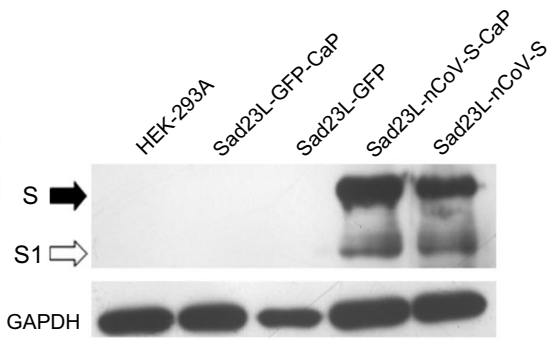

Sad23L-nCoV-S-CaP

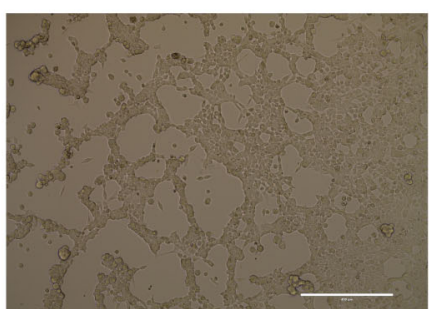

Fig. 1 Production of Sad23L-nCoV-S-CaP vaccines. A Schematic diagram for self-biomineralization of Sad23L with CaP. B Sad23LnCoV-S vaccine strains under transmission electron microscopy (TEM) with phosphotungstic acid negative staining (scale bar: $100 \mathrm{~nm}$ ). C Observation of Sad23L-nCoV-S-CaP particles under SEM. D Energy dispersive X-ray (EDX) examination for ion phases of Sad23L-nCoV-S-CaP vaccine. E TEM observation of Sad23L$\mathrm{nCoV}-\mathrm{S}-\mathrm{CaP}$ virons without staining $(\mathrm{pH}=7.6)$ (scale bar: $100 \mathrm{~nm}$; inset). F Dot blot assay of Sad23L-nCoV-S and Sad23L-nCoV-S-CaP

Sad23L-nCoV-S-CaP vaccine in comparing with Sad23LnCoV-S vaccine, Sad23L-GFP and an equal volume of $\mathrm{CaP}$ controls (Fig. 3A; Supplementary Table S1). After 4 weeks post-immunization, the specific serum binding antibody $(\mathrm{BAb})$ to $\mathrm{S} 1$ or $\mathrm{S} 2$ protein (S1-BAb or $\mathrm{S} 2-\mathrm{BAb})$ was measured by ELISA. Sad23L-nCoV-S-CaP vaccine raised vaccines under native or denatured condition using anti-Sad23L antibody. CaP was used as background control. G Western blot analysis for S protein expression from Sad23L-nCoV-S or Sad23LnCoV-S-CaP infected HEK-293A cells by rabbit polyclonal antibody specific to RBD. Sad23L-GFP and Sad23L-GFP-CaP vectorial virus infected cells were used as negative controls. H Cytopathic effect of Sad23L-nCoV-S and Sad23L-nCoV-S-CaP infected HEK-293A cells at $48 \mathrm{~h}$ post infection. Scale bar $=400 \mu \mathrm{m}$.

$\mathrm{BAb}$ titers of $10^{4.63}$ to $\mathrm{S} 1$ and $10^{4.08}$ to $\mathrm{S} 2$, respectively, which were the same with Sad23L-nCoV-S vaccine $\left(10^{4.55}\right.$ $\mathrm{S} 1-\mathrm{BAb}$ and $\left.10^{3.93} \mathrm{~S} 2-\mathrm{BAb}\right)$ but significantly higher than the control groups $(P<0.001$, Fig. 3B, 3C). The neutralizing antibody (NAb) to SARS-CoV-2 were quantified by pseudovirus-based NAb test (pVNT) at 50\% inhibition 

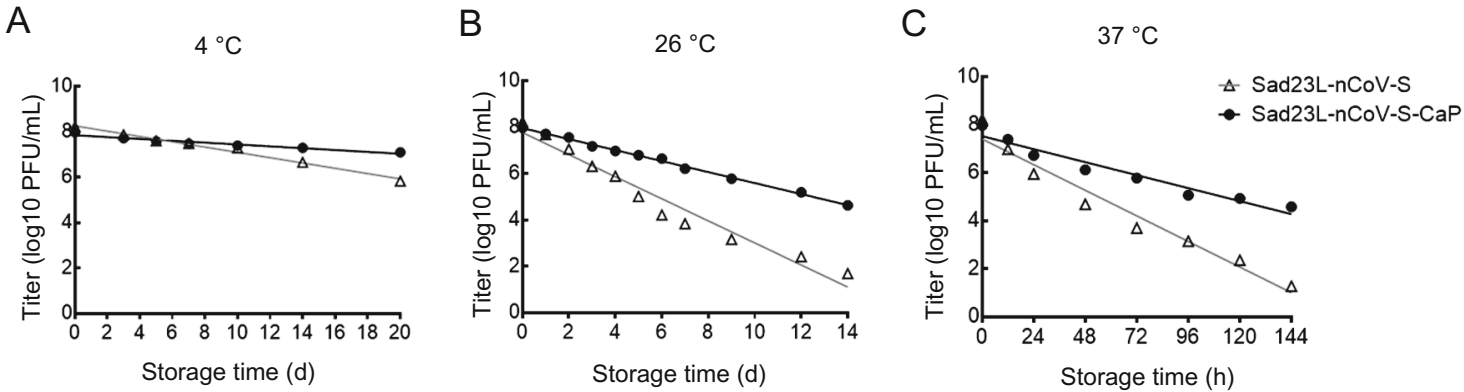

Fig. 2 The thermostability of Sad23L-nCoV-S-CaP and Sad23LnCoV-S vaccines were tested at $4{ }^{\circ} \mathrm{C}(\mathbf{A}), 26{ }^{\circ} \mathrm{C}(\mathbf{B})$ or $37{ }^{\circ} \mathrm{C}(\mathbf{C})$. The infectivity titer is determined by plaque forming assay in HEK293 A cells, which is represented in a logarithmic scale as a function of incubation time. Data is shown as mean from three independent

experiments. The calculated average inactivation rate constants, $K_{\mathrm{Sad} 23 \mathrm{~L}-\mathrm{nCoV}-\mathrm{S}}=0.1167 \mathrm{~d}^{-1}$ and $K_{\mathrm{Sad} 23 \mathrm{~L}-\mathrm{nCoV}-\mathrm{S}-\mathrm{CaP}}=0.0408 \mathrm{~d}^{-1}$ at $4{ }^{\circ} \mathrm{C} ; K_{\mathrm{Sad} 23 \mathrm{~L}-n \mathrm{nCoV}-\mathrm{S}}=0.476 \mathrm{~d}^{-1}$ and $K_{\mathrm{Sad} 23 \mathrm{~L}-\mathrm{nCoV}-\mathrm{S}-\mathrm{CaP}}=0.2372 \mathrm{~d}^{-1}$ at $26{ }^{\circ} \mathrm{C} ; \quad K_{\mathrm{Sad} 23 \mathrm{~L}-\mathrm{nCoV}-\mathrm{s}}=0.04445 \mathrm{~h}^{-1}$ and $K_{\mathrm{Sad} 23 \mathrm{~L}-\mathrm{nCoV}-\mathrm{S}-\mathrm{CaP}}$ $=0.02256 \mathrm{~h}^{-1}$ at $37^{\circ} \mathrm{C}$.
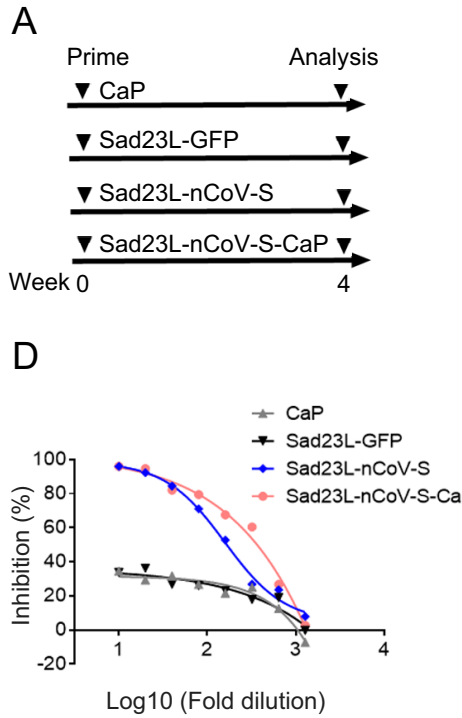
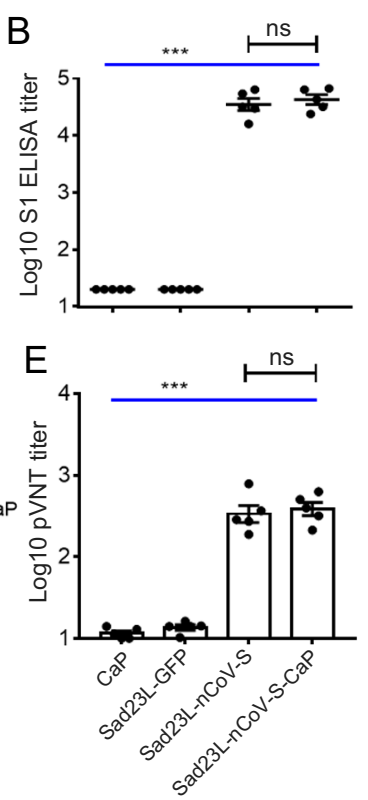

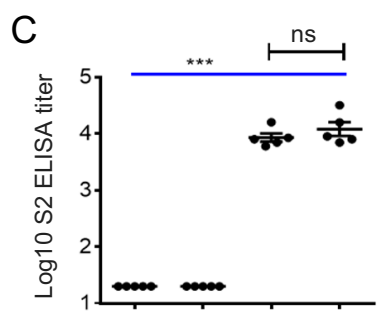

F

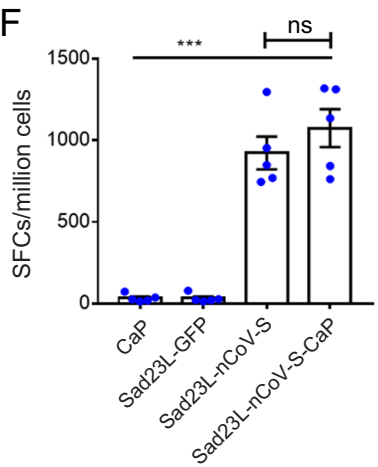

Fig. 3 The immunogenicity of Sad23L-nCoV-S-CaP vaccine. A BALB/c mice $(\mathrm{n}=5 /$ group $)$ were immunized with $10^{7} \mathrm{PFU}$ Sad23L-nCoV-S or Sad23L-nCoV-S-CaP. Sera and splenocytes were collected for the detection of antibody and $\mathrm{T}$ cell response 4-week post-immunization. B S1-BAb or C S2-BAb titers were measured by ELISA. D Inhibition of SARS-CoV-2 pseudovirus by anti-sera from vaccinated or control mice. $\mathbf{E}$ NAb titers were measured by

concentration $\left(\mathrm{IC}_{50}\right)$ (Fig. 3D). Similarly, Sad23L-nCoV$\mathrm{S}-\mathrm{CaP}$ vaccine induced NAb titer of $10^{2.59} \mathrm{pVNT}\left(\mathrm{IC}_{50}\right)$ equal to Sad23L-nCoV-S vaccine induced NAb titer $\left(10^{2.53}\right.$ pVNT at $\mathrm{IC}_{50}$ ) (Fig. 3E).

Specific T-cell response of splenocytes to $\mathrm{S}$ peptides was detected by ELISpot (Fig. 3F; Supplementary Fig. S2). The IFN- $\gamma$ secreting $\mathrm{T}$ cell response was 1075.36 SFCs/ million cells in Sad23L-nCoV-S-CaP vaccine injected pseudovirus neutralization test. F IFN- $\gamma$ secreting $\mathrm{T}$ cell response (SFCs/million cells) of splenocytes to $\mathrm{S}$ peptides was measured by ELISpot. Data is shown as mean \pm SEM. $P$ values are analyzed by one-way ANOVA with twofold Bonferroni adjustment. Statistically significant differences are shown with asterisks $(* * *, P<0.001 ; \mathrm{ns}$, $P>0.05$ or no significant difference).

mice while the similar level of $923.21 \mathrm{SFCs} /$ million cells was in Sad23L-nCoV-S vaccine group (Fig. 3F). Both vaccines elicited $\mathrm{T}$ cell response significantly higher than sham controls $(P<0.001)$.

Overall, the self-biomineralized vaccine can develop high level of specific humoral and $\mathrm{T}$ cell responses to SARS-CoV-2 $\mathrm{S}$ antigen in mice, suggesting Sad23LnCoV-S-CaP vaccine carries strong immunogenicity. 
A
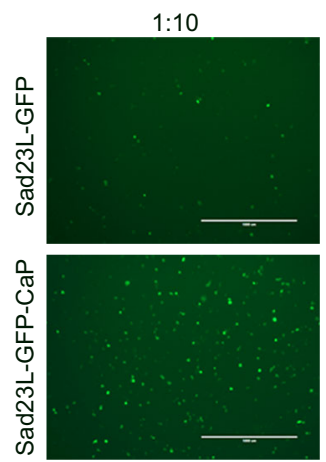

$\mathrm{B}$

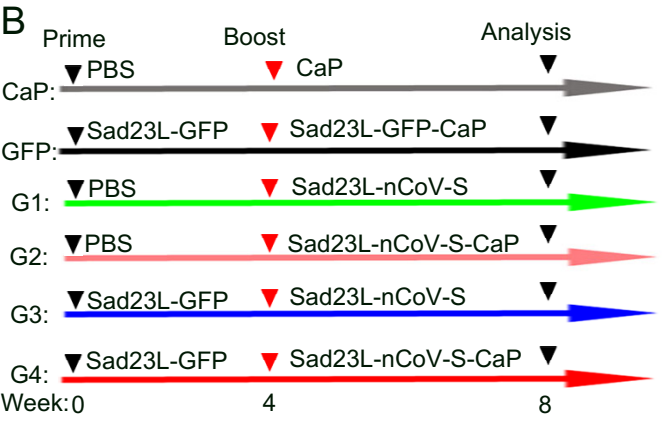

$\mathrm{E}$

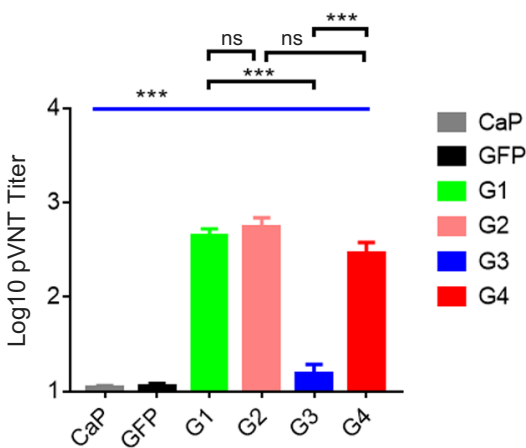

G

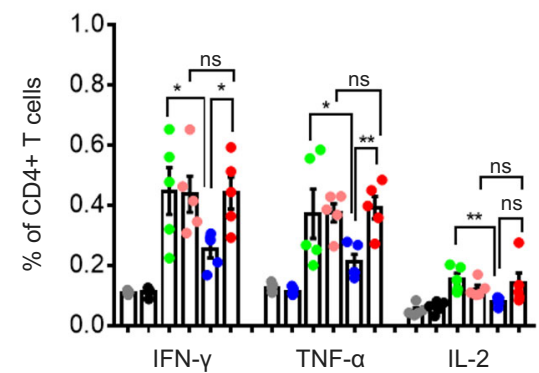

Fig. 4 The self-biomineralized Sad23L virus escaped pre-existing immunity in vitro and in vivo. A Neutralization of Sad23L-GFP and Sad23L-GFP-CaP in HEK-293A cells with anti-Sad23L serum. Scale bar $=1 \mathrm{~mm}$. B Immunization regimen in naïve and Sad23L preexposed mice. C S1-BAb or D S2-BAb titers were detected by ELISA. E NAb titers were obtained by pVNT. F Splenocytes was stimulated by $\mathrm{S}$ peptides and $\mathrm{T}$ cell response and measured by

C

$\mathrm{F}$

$\mathrm{H}$
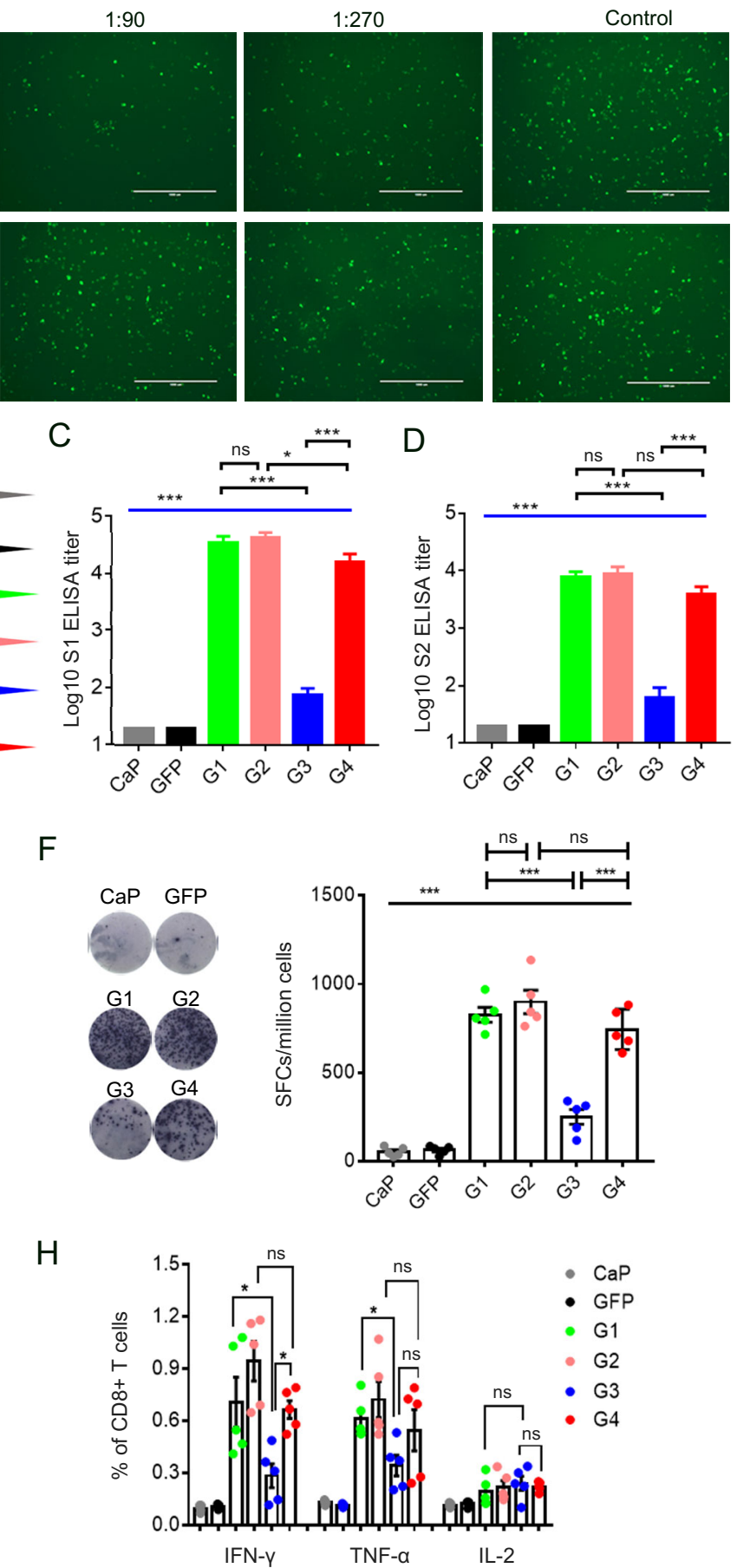

ELISpot. Frequency of intracellular IFN- $\gamma$, TNF- $\alpha$ or IL-2 expressing in $\mathrm{CD}^{+}(\mathbf{G})$ or $\mathrm{CD}^{+}(\mathbf{H}) \mathrm{T}$ cell response to $\mathrm{S}$ peptides was determined by ICS, respectively. Data is shown as mean \pm SEM. $P$ values are analyzed by one-way ANOVA and unpaired $t$ test. Statistically significant differences are shown with asterisks (*, $P<0.05$; **, $P<0.01$; ***, $P<0.001$ and ns, $P>0.05$ or no significant difference). 


\section{The Self-Biomineralized Virus Avoided Impact of Preexisting Immunity on Boosting Immunization In Vitro and In Vivo}

The influence of preexisting immunity of adenovirus vector Sad23L was compared between Sad23L-GFP-CaP and Sad23L-GFP virus. Mouse anti-Sad23L serum inhibited Sad23L-GFP virus infection in HEK-293A cells, of which the GFP fluorescent signal was remarkably reduced depending on the dilution of antiserum (Fig. 4A, upper panel), while the anti-Sad23L serum did not neutralize Sad23L-GFP-CaP infection in cells (Fig. 4A, lower panel). The results suggested that CaP-coated Sad23L-GFP virus (Sad23L-GFP-CaP) could avoid being neutralized by antiSad23L antibody in vitro.

In order to explore whether Sad23L-nCoV-S-CaP vaccine could evade pre-existing immunity in vivo, three groups of naïve mice were prime immunized with $10^{7} \mathrm{PFU}$ Sad23L-GFP virus, and the neutralizing antibody (NAb) to Sad23L-GFP was determined as 1:906.67 (mean) in week 4 (Supplementary Fig. S3). These Sad23L pre-exposed mice were secondarily injected with $10^{7}$ PFU Sad23L-GFP-CaP (GFP), Sad23L-nCoV-S (G3) or Sad23L-nCoV-S-CaP (G4) virus in the boost immunization, respectively. In comparison, Sad23L non-exposed (PBS injected) mice were inoculated with $\mathrm{CaP}(\mathrm{CaP}), \mathrm{Sad} 23 \mathrm{~L}-\mathrm{nCoV}-\mathrm{S}(\mathrm{G} 1)$ or Sad23L-nCoV-S-CaP (G2) viruses (Fig. 4B; Supplementary Table S2). Serum S1-BAb or S2-BAb titers were detected by ELISA after four weeks post boost-immunization. The mean endpoint $\mathrm{S} 1-\mathrm{BAb}$ titers were $10^{4.45}$ in $\mathrm{G} 1,10^{4.57}$ in $\mathrm{G} 2,10^{1.87}$ in G3 or $10^{4.21}$ in G4 group (Fig. 4C), and corresponding S2-BAb titers were $10^{3.89}$, $10^{3.91}, 10^{1.79}$ or $10^{3.59}$ in $\mathrm{G} 1$ to G4 group (Fig. 4D), respectively, but no $\mathrm{S} 1-\mathrm{BAb}$ or $\mathrm{S} 2-\mathrm{BAb}$ were detected in $\mathrm{CaP}$ and GFP control mice $(P<0.001)$. NAb $(\mathrm{pVNT})$ titers to SARS-CoV-2 were tested for $10^{2.65}(\mathrm{G} 1), 10^{2.74}$ (G2), $10^{1.18}(\mathrm{G} 3)$ and $10^{2.46}(\mathrm{G} 4)$, respectively (Fig. 4E; Supplementary Fig. S4). Sad23L-nCoV-S-CaP vaccine group (G4) exhibited significantly higher S1-BAb, S2-BAb and pVNT titers than Sad23L-nCoV-S vaccine group (G3) based on Sad23L pre-exposed mice (Fig. 4C-4E, $P<0.001)$.

Specific $\mathrm{T}$ cell response to $\mathrm{S}$ peptides was measured by ELISpot after 4 weeks post boost-immunization of mice. The IFN- $\gamma$ secretion T cell response of Sad23L-nCoV-S$\mathrm{CaP}\left(\mathrm{G} 4,744.8 \mathrm{SFCs} / 10^{6}\right.$ cells) in Sad23L pre-exposed mice paralleled with $\mathrm{G} 1$ (827.4 $\mathrm{SFCs} / 10^{6}$ cells) and G2 (899.6 SFCs $/ 10^{6}$ cells) in Sad23L non-exposed mice (Fig. 4F, $P>0.05$ ), which was significantly higher than Sad23L-nCoV-S (G3, 251.4 SFCs $/ 10^{6}$ cells) in Sad23L pre-exposed mice, $\mathrm{CaP}$ and GFP control groups (Fig. 4F, $P<0.001)$. Frequency of intracellular IFN- $\gamma$, TNF- $\alpha$ and
IL-2 expressing $\mathrm{CD}^{+}{ }^{+}$or $\mathrm{CD} 8^{+} \mathrm{T}$ cell response to $\mathrm{S}$ peptides was measured by ICS (Fig. 4G, 4H; Supplementary Fig. S5), in which G4, G1 and G2 induced similar IFN- $\gamma$ or TNF- $\alpha$ expressing $\mathrm{CD} 4^{+} / \mathrm{CD} 8^{+} \mathrm{T}$ cell response, but significantly higher than Sad23L-nCoV-S (G3) in Sad23L preexposed mice $(P<0.05)$. Four groups $(\mathrm{G} 1$ to $\mathrm{G} 4)$ varied insignificantly in intracellular IL-2 expressing $\mathrm{CD} 4^{+} / \mathrm{CD} 8^{+}$ $\mathrm{T}$ cell responses (Fig. 4G, 4H; Supplementary Fig. S5).

\section{Prime-Boost Immunizations of Mice with Sad23L- nCoV-S and Sad23L-nCoV-S-CaP Vaccines}

The prime-boost regimen was applied for inoculating $\mathrm{BALB} / \mathrm{c}$ mice $(\mathrm{n}=5 /$ group $)$ by priming with $10^{7} \mathrm{PFU}$ Sad23L-nCoV-S and boosting with $10^{7}$ PFU Sad23LnCoV-S (V1) or Sad23L-nCoV-S-CaP (V2) at 4-week interval in comparison with $\mathrm{PBS} / \mathrm{CaP}(\mathrm{CaP})$ and $\mathrm{Sad} 23 \mathrm{~L}$ GFP/Sad23L-GFP-CaP (GFP) control groups (Fig. 5A; Supplementary Table S3). The booster V2 induced significantly higher $\mathrm{S} 1-\mathrm{BAb}$ titer $\left(10^{5.01}\right)$ than the booster $\mathrm{V} 1$ $\left(10^{4.83}\right)(P=0.038$, Fig. 5B), while the booster V2 or V1 raised similar $\mathrm{S} 2-\mathrm{BAb}\left(10^{4.71}\right.$ vs $10^{4.77}, P>0.05$, Fig. $\left.5 \mathrm{C}\right)$ and pVNT NAb titers $\left(10^{3.04}\right.$ vs $10^{2.78}, P>0.05$, Fig. 5D), respectively.

Regarding to specific $\mathrm{T}$ cell response to $\mathrm{S}$ peptides (Fig. 5E), the booster Sad23L-nCoV-S-CaP induced the higher level of specific IFN- $\gamma$ secreting $\mathrm{T}$ cell response (1466.16 SFCs $/ 10^{6}$ cells) in V2 than Sad23L-nCoV-S in V1 (1170 SFCs $/ 10^{6}$ cells, $\left.P=0.0016\right)$. In contrast, the frequency of IFN- $\gamma$, TNF- $\alpha$ and IL- 2 of $\mathrm{CD} 4^{+}$and $\mathrm{CD} 8^{+} \mathrm{T}$ cell responses were not statistically different between $\mathrm{V} 1$ and V2 $(P>0.05)$ (Fig. 5F-5I), excepting for that the higher frequency of TNF- $\alpha$ producing $\mathrm{CD}^{+} \mathrm{T}$ cell response in V2 $(0.81 \%)$ than V1 $(0.53 \%)(P=0.0409$, Fig. 5I).

Taken together, the results suggest that priming immunization with Sad23L-nCoV-S vaccine and boosting with self-biomineralized Sad23L-nCoV-S-CaP vaccine could elicit higher immune response to SARS-CoV-2 antigen than a single shot of Sad23L-nCoV-S or Sad23L-nCoV-S$\mathrm{CaP}$ vaccine (Supplementary Fig. S6).

\section{Discussion}

Although 102 COVID-19 candidate vaccines are in clinical trials (15 June 2021, WHO report), and some of them have been approved or registered for emerging use, the development of safe, thermostable, effective and easily produced COVID-19 vaccines is still a big challenge, especially for the vaccines used in the poorest countries. Our study may provide an alternative vaccine candidate. 
A

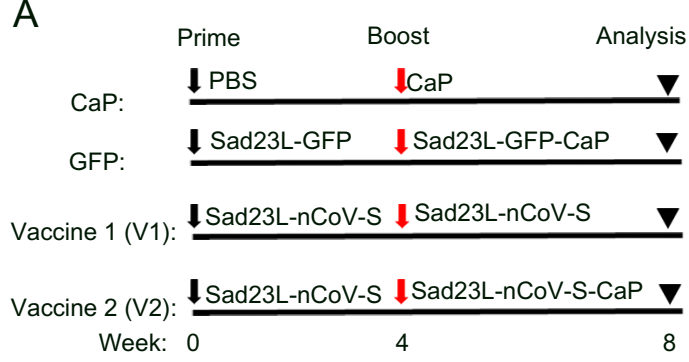

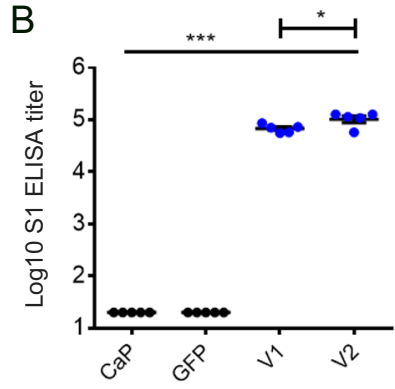
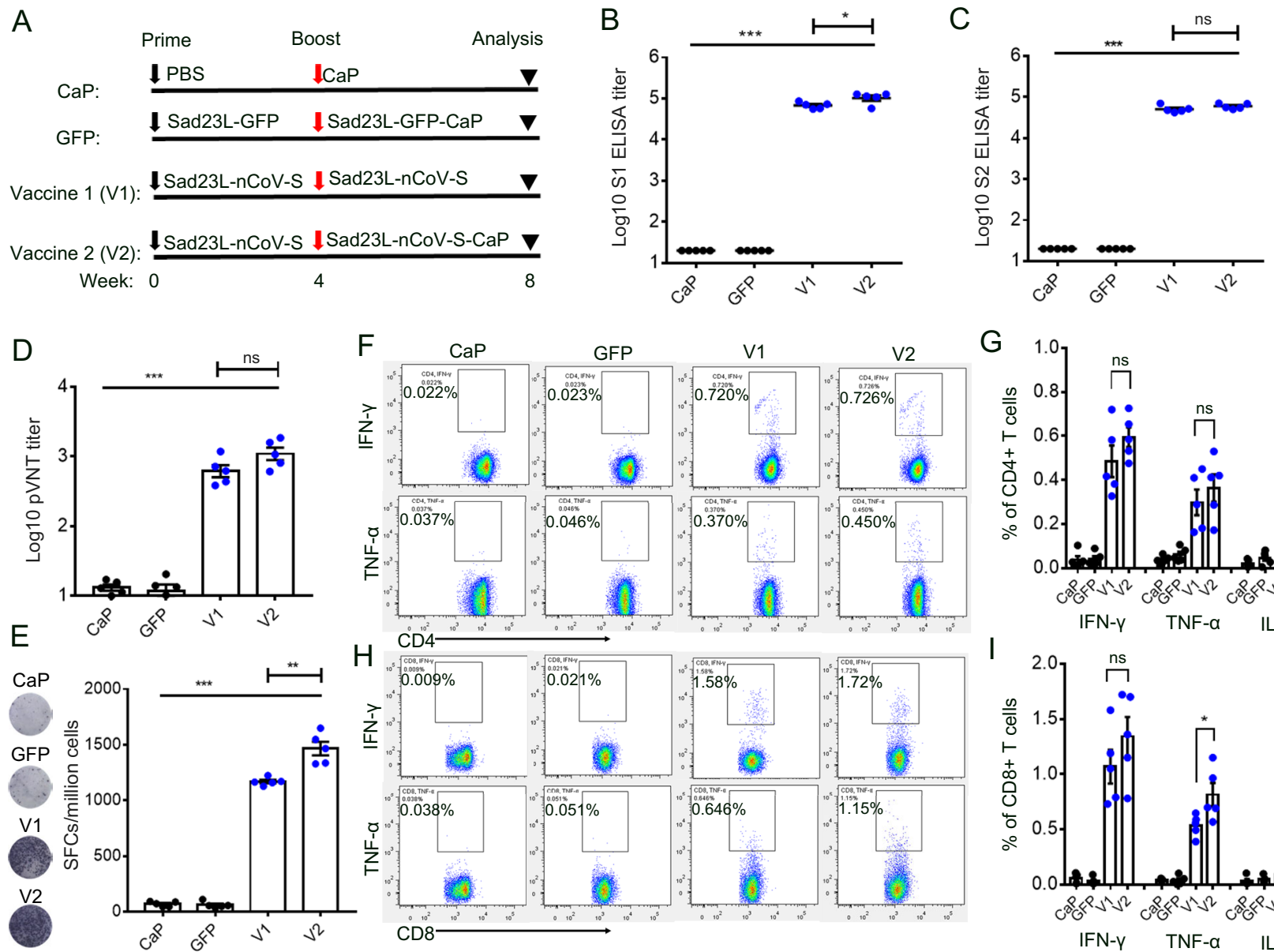

Fig. 5 Specific humoral and $\mathrm{T}$ cell response of mice immunized with Sad23L-nCoV-S and Sad23L-nCoV-S-CaP vaccine by prime-boost regimen. A Immunization regimen. (B) S1-BAb or (C) S2-BAb titers were tested by ELISA. D NAb titers were measured by pVNT $\left(\mathrm{IC}_{50}\right)$. E IFN- $\gamma$ secreting level to $S$ peptides was measured by ELISpot. (FI) Frequency of intracellular IFN- $\gamma$, TNF- $\alpha$ and IL-2 expressing

In this study, we evaluated a novel adenovirus vector vaccine Sad23L-nCoV-S and its self-biomineralized form Sad23L-nCoV-S-CaP vaccine in prime-boost vaccination regimen. The self-biomineralization could improve the thermostability and immunogenicity of the vaccine, and overcome the preexisting anti-vector immunity from priming immunization with Sad23L-nCoV-S when it was used as a booster in vaccination. In comparison with other COVID-19 vaccines, the immunization regimen by priming with Sad23L-nCoV-S and boosting with Sad23L$\mathrm{nCoV}-\mathrm{S}-\mathrm{CaP}$ vaccines presented several advantages, which are highlighted below as four attractive aspects.

Firstly, the novel adenovirus vector Sad23L is lowseroprevalence in humans. Comparing with over $75 \%$ prevalence of Ad5 in Chinese population, NAb prevalence of $\mathrm{Sad} 23 \mathrm{~L}$ is less than $10 \%$, suggesting that $\mathrm{Sad} 23 \mathrm{~L}$ can be a better vector for vaccine development and avoid the
$\mathrm{CD}^{+}$or $\mathrm{CD}^{+} \mathrm{T}$ cell response to $\mathrm{S}$ peptides was determined by intracellular cytokine staining, respectively. Data are shown as mean \pm SEM. $P$ values are calculated with two-tailed $t$ test. Statistically significant differences are shown with asterisks $(*, P<0.05$; **, $P<0.01$; ***, $P<0.001$; ns, $P>0.05$ or no significant difference).

preexisting immunity to common human adenoviruses (Luo et al. 2019, 2020, 2021).

Secondly, CaP-masked vaccine (Sad23L-nCoV-S-CaP) could be considered as the vaccine that had a shell to protect the vaccine from preexisting antibody binding and improve its storage stability at room temperature. Therefore, this Sad23L-nCoV-S-CaP vaccine is particularly suitable for application in developing countries, where the vaccine delivery can be less dependent on cold-chain.

Thirdly, the self-biomineralized Sad23L-nCoV-S-CaP retained high immunogenicity and could induce stronger humoral and cellular immune response in mice than Sad23L-nCoV-S (Fig. 3).

Fourthly, the self-biomineralized vaccine could overcome preexisting anti-Sad23L immunity in vitro and in vivo. Furthermore, Sad23L-nCoV-S-CaP induced significantly higher S1-BAb, S2-BAb, NAb, and specific IFN- $\gamma$ secreting 
$\mathrm{T}$ cell response, and IFN- $\gamma$ or TNF- $\alpha$ expressing $\mathrm{CD}^{+}{ }^{+}$, $\mathrm{CD} 8{ }^{+} \mathrm{T}$ cell responses than Sad23L-nCoV-S in Sad23L preexposed mice (Fig. 4; Supplementary Fig. S6). Therefore, two inoculations of vaccines for prime-boost vaccination become possible, in which Sad23L-nCoV-S and Sad23LnCoV-S-CaP are used as priming and boosting immunization, respectively. Compared with homologous boosting of ChAdOx1 nCoV-19 or Ad5-S vaccines (Graham et al. 2020; Logunov et al. 2020), the prime-boost vaccination regimen with Sad23L-nCoV-S and Sad23L-nCoV-S-CaP vaccines has the advantage of avoiding vector's immunity from priming immunization (Luo et al. 2019, 2020, 2021).

In this study, a self-biomineralized Sad23L-nCoV-S$\mathrm{CaP}$ vaccine was evaluated in comparison with Sad23LnCoV-S vaccine, which had better thermostability and was able to induce robust humoral and cellular immune responses in mice. Sad23L-nCoV-S-CaP vaccine could be used as a booster in combination with priming vaccine Sad23L-nCoV-S for prime-boost vaccinations against SARS-CoV-2 infection in humans.

Acknowledgements The authors thank professors Kwok-Yung Yuen from The University of Hong Kong for his assistance for purchasing simian adenoviruses type 23; Dongming Zhou from The Institut Pasteur in Shanghai for his technical help for construction of adenovirus vectors. This work was supported by the grants from the National Natural Science Foundation of China (No. 32070929, 81871655 and 31770185), the Special Funding for COVID-19 Prevention and Control of China (2020M670013ZX), the China Postdoctoral Science Foundation (2021M691474) and Guangzhou Bai Rui Kang (BRK) Biological Science and Technology Limited Company, China. The funders had no role in study design, data collection and analysis, decision to publish, or preparation of the manuscript.

Author Contribution CL, YZ, SL, PZ and LZ conceived and designed the experiments. SL, PZ, PZ, CW, BL, CW and TL performed the experiments. CL, SL, YZ and LZ wrote the manuscript. YZ and LZ revised and finalized the article. All authors read and approved the final version of the manuscript.

\section{Compliance with Ethical standards}

Conflict of interest All authors declare no conflicts of interest.

Animal and Human Rights Statement All animal care and experimental procedures were in accordance with the Guidelines for the Care and Use of Laboratory Animals issued by Southern Medical University [permit numbers: SYXK (Yue) 2010-0056].

\section{References}

Abbink P, Maxfield LF, Ng'ang'a D, Borducchi EN, Iampietro MJ, Bricault CA, Teigler JE, Blackmore S, Parenteau L, Wagh K, Handley SA, Zhao G, Virgin HW, Korber B, Barouch DH (2015) Construction and evaluation of novel rhesus monkey adenovirus vaccine vectors. J Virol 89:1512-1522

Amanat F, Krammer F (2020) Sars-cov-2 vaccines: status report. Immunity 52:583-589
Corbett KS, Flynn B, Foulds KE, Francica JR, Boyoglu-Barnum S, Werner AP, Flach B, O'Connell S, Bock KW, Minai M, Nagata BM, Andersen H, Martinez DR, Noe AT, Douek N, Donaldson MM, Nji NN, Alvarado GS, Edwards DK, Flebbe DR, Lamb E, Doria-Rose NA, Lin BC, Louder MK, O'Dell S, Schmidt SD, Phung E, Chang LA, Yap C, Todd J-PM, Pessaint L, Van Ry A, Browne S, Greenhouse J, Putman-Taylor T, Strasbaugh A, Campbell T-A, Cook A, Dodson A, Steingrebe K, Shi W, Zhang Y, Abiona OM, Wang L, Pegu A, Yang ES, Leung K, Zhou T, Teng IT, Widge A, Gordon I, Novik L, Gillespie RA, Loomis RJ, Moliva JI, Stewart-Jones G, Himansu S, Kong W-P, Nason MC, Morabito KM, Ruckwardt TJ, Ledgerwood JE, Gaudinski MR, Kwong PD, Mascola JR, Carfi A, Lewis MG, Baric RS, McDermott A, Moore IN, Sullivan NJ, Roederer M, Seder RA, Graham BS (2020) Evaluation of the mrna-1273 vaccine against sars-cov-2 in nonhuman primates. N Engl J Med 383:1544-1555

Dorozhkin SV (2013) A detailed history of calcium orthophosphates from 1770s till 1950. Mater Sci Eng C Mater Biol Appl 33:3085-3110

Folegatti PM, Ewer KJ, Aley PK, Angus B, Becker S, BelijRammerstorfer S, Bellamy D, Bibi S, Bittaye M, Clutterbuck EA, Dold C, Faust SN, Finn A, Flaxman AL, Hallis B, Heath P, Jenkin D, Lazarus R, Makinson R, Minassian AM, Pollock KM, Ramasamy M, Robinson H, Snape M, Tarrant R, Voysey M, Green C, Douglas AD, Hill AVS, Lambe T, Gilbert SC, Pollard AJ (2020) Safety and immunogenicity of the chadox 1 ncov-19 vaccine against sars-cov-2: a preliminary report of a phase $1 / 2$, single-blind, randomised controlled trial. Lancet 396:467-478

Gao Q, Bao L, Mao H, Wang L, Xu K, Yang M, Li Y, Zhu L, Wang N, Lv Z, Gao H, Ge X, Kan B, Hu Y, Liu J, Cai F, Jiang D, Yin Y, Qin C, Li J, Gong X, Lou X, Shi W, Wu D, Zhang H, Zhu L, Deng W, Li Y, Lu J, Li C, Wang X, Yin W, Zhang Y, Qin C (2020) Development of an inactivated vaccine candidate for sars-cov-2. Science 369:77-81

Graham SP, McLean RK, Spencer AJ, Belij-Rammerstorfer S, Wright D, Ulaszewska M, Edwards JC, Hayes JWP, Martini V, Thakur N, Conceicao C, Dietrich I, Shelton H, Waters R, Ludi A, Wilsden G, Browning C, Bialy D, Bhat S, Stevenson-Leggett P, Hollinghurst P, Gilbride C, Pulido D, Moffat K, Sharpe H, Allen E, Mioulet V, Chiu C, Newman J, Asfor AS, Burman A, Crossley S, Huo JD, Owens RJ, Carroll M, Hammond JA, Tchilian E, Bailey D, Charleston B, Gilbert SC, Tuthill TJ, Lambe T (2020) Evaluation of the immunogenicity of primeboost vaccination with the replication-deficient viral vectored covid-19 vaccine candidate chadox 1 ncov-19. NPJ Vaccines 5:69

Jackson LA, Anderson EJ, Rouphael NG, Roberts PC, Makhene M, Coler RN, McCullough MP, Chappell JD, Denison MR, Stevens LJ, Pruijssers AJ, McDermott A, Flach B, Doria-Rose NA, Corbett KS, Morabito KM, O’Dell S, Schmidt SD, Swanson PA 2nd, Padilla M, Mascola JR, Neuzil KM, Bennett H, Sun W, Peters E, Makowski M, Albert J, Cross K, Buchanan W, PikaartTautges R, Ledgerwood JE, Graham BS, Beigel JH, m RNASG (2020) An mrna vaccine against sars-cov-2 - preliminary report. N Engl J Med 383:1920-1931

Jiang D, Premachandra GS, Johnston C, Hem SL (2004) Structure and adsorption properties of commercial calcium phosphate adjuvant. Vaccine 23:693-698

Lin Y, Wang X, Huang X, Zhang J, Xia N, Zhao Q (2017) Calcium phosphate nanoparticles as a new generation vaccine adjuvant. Expert Rev Vaccines 16:895-906

Lin J, Wang X, Tang R (2019) Regulations of organism by materials: a new understanding of biological inorganic chemistry. J Biol Inorg Chem 24:467-482

Logunov DY, Dolzhikova IV, Zubkova OV, Tukhvatullin AI, Shcheblyakov DV, Dzharullaeva AS, Grousova DM, Erokhova 
AS, Kovyrshina AV, Botikov AG, Izhaeva FM, Popova O, Ozharovskaya TA, Esmagambetov IB, Favorskaya IA, Zrelkin DI, Voronina DV, Shcherbinin DN, Semikhin AS, Simakova YV, Tokarskaya EA, Lubenets NL, Egorova DA, Shmarov MM, Nikitenko NA, Morozova LF, Smolyarchuk EA, Kryukov EV, Babira VF, Borisevich SV, Naroditsky BS, Gintsburg AL (2020) Safety and immunogenicity of an rad26 and rad5 vector-based heterologous prime-boost covid-19 vaccine in two formulations: two open, non-randomised phase 1/2 studies from Russia. Lancet 396:887-897

Lu R, Zhao X, Li J, Niu P, Yang B, Wu H, Wang W, Song H, Huang B, Zhu N, Bi Y, Ma X, Zhan F, Wang L, Hu T, Zhou H, Hu Z, Zhou W, Zhao L, Chen J, Meng Y, Wang J, Lin Y, Yuan J, Xie Z, Ma J, Liu WJ, Wang D, Xu W, Holmes EC, Gao GF, Wu G, Chen W, Shi W, Tan W (2020) Genomic characterisation and epidemiology of 2019 novel coronavirus: implications for virus origins and receptor binding. Lancet 395:565-574

Luo S, Zhang P, Ma X, Wang Q, Lu J, Liu B, Zhao W, Allain JP, Li C, Li T (2019) A rapid strategy for constructing novel simian adenovirus vectors with high viral titer and expressing highly antigenic proteins applicable for vaccine development. Virus Res 268:1-10

Luo S, Zhang P, Liu B, Yang C, Liang C, Wang Q, Zhang L, Tang X, Li J, Hou S, Zeng J, Fu Y, Allain J-P, Li T, Zhang Y, Li C (2021) Prime-boost vaccination of mice and rhesus macaques with two novel adenovirus vectored covid-19 vaccine candidates. Emerg Microbes Infect 10:1002-1015

Luo S, Zhao W, Ma X, Zhang P, Liu B, Zhang L, Wang W, Wang Y, Fu Y, Allain J-P, Li T, Li C (2020) A high infectious simian adenovirus type 23 vector based vaccine efficiently protects common marmosets against zika virus infection. Plos Negl Trop Dis 14:e0008027

Mercado NB, Zahn R, Wegmann F, Loos C, Chandrashekar A, Yu J, Liu J, Peter L, McMahan K, Tostanoski LH, He X, Martinez DR, Rutten L, Bos R, van Manen D, Vellinga J, Custers J, Langedijk JP, Kwaks T, Bakkers MJG, Zuijdgeest D, Huber SKR, Atyeo C, Fischinger S, Burke JS, Feldman J, Hauser BM, Caradonna TM, Bondzie EA, Dagotto G, Gebre MS, Hoffman E, Jacob-Dolan C, Kirilova M, Li Z, Lin Z, Mahrokhian SH, Maxfield LF, Nampanya F, Nityanandam R, Nkolola JP, Patel S, Ventura JD, Verrington $\mathrm{K}$, Wan $\mathrm{H}$, Pessaint L, Ry AV, Blade $\mathrm{K}$, Strasbaugh A, Cabus M, Brown R, Cook A, Zouantchangadou S, Teow E, Andersen H, Lewis MG, Cai Y, Chen B, Schmidt AG, Reeves RK, Baric RS, Lauffenburger DA, Alter G, Stoffels P, Mammen M, Hoof JV, Schuitemaker H, Barouch DH (2020) Single-shot ad26 vaccine protects against sars-cov-2 in rhesus macaques. Nature 586:583-588

Mulligan MJ, Lyke KE, Kitchin N, Absalon J, Gurtman A, Lockhart S, Neuzil K, Raabe V, Bailey R, Swanson KA, Li P, Koury K, Kalina W, Cooper D, Fontes-Garfias C, Shi P-Y, Tureci O, Tompkins KR, Walsh EE, Frenck R, Falsey AR, Dormitzer PR, Gruber WC, Sahin U, Jansen KU (2020) Phase 1/2 study of covid-19 rna vaccine bnt162b1 in adults. Nature 586:589-593

Shen H, Tan J, Saltzman WM (2004) Surface-mediated gene transfer from nanocomposites of controlled texture. Nat Mater 3:569-574

Srinivasan S, Cui H, Gao Z, Liu M, Lu S, Mkandawire W, Narykov O, Sun M, Korkin D (2020) Structural genomics of sars-cov-2 indicates evolutionary conserved functional regions of viral proteins. Viruses 12:360

Tostanoski LH, Wegmann F, Martinot AJ, Loos C, McMahan K, Mercado NB, Yu J, Chan CN, Bondoc S, Starke CE, Nekorchuk M, Busman-Sahay K, Piedra-Mora C, Wrijil LM, Ducat S, Custers J, Atyeo C, Fischinger S, Burke JS, Feldman J, Hauser BM, Caradonna TM, Bondzie EA, Dagotto G, Gebre MS (2020) Ad26 vaccine protects against sars-cov-2 severe clinical disease in hamsters. Nat Med 26:1694-1700 van Doremalen N, Lambe T, Spencer A, Belij-Rammerstorfer S, Purushotham JN, Port JR, Avanzato VA, Bushmaker T, Flaxman A, Ulaszewska M, Feldmann F, Allen ER, Sharpe H, Schulz J, Holbrook M, Okumura A, Meade-White K, Pérez-Pérez L, Edwards NJ, Wright D, Bissett C, Gilbride C, Williamson BN, Rosenke R, Long D, Ishwarbhai A, Kailath R, Rose L, Morris S, Powers C, Lovaglio J, Hanley PW, Scott D, Saturday G, de Wit E, Gilbert SC, Munster VJ (2020) ChAdOx1 nCoV-19 vaccine prevents SARS-CoV-2 pneumonia in rhesus macaques. Nature 586:578-582

Walls AC, Park YJ, Tortorici MA, Wall A, McGuire AT, Veesler D (2020) Structure, function, and antigenicity of the sars-cov-2 spike glycoprotein. Cell 181:281-292

Walters R, Welsh M (1999) Mechanism by which calcium phosphate coprecipitation enhances adenovirus-mediated gene transfer. Gene Ther 6:1845-1850

Wang X, Deng Y, Li S, Wang G, Qin E, Xu X, Tang R, Qin C (2012) Biomineralization-based virus shell-engineering: Towards neutralization escape and tropism expansion. Adv Healthc Mater 1:443-449

Wang G, Cao RY, Chen R, Mo L, Han JF, Wang X, Xu X, Jiang T, Deng YQ, Lyu K, Zhu SY, Qin ED, Tang R, Qin CF (2013) Rational design of thermostable vaccines by engineered peptideinduced virus self-biomineralization under physiological conditions. Proc Natl Acad Sci U S A 110:7619-7624

Wang X, Sun C, Li P, Wu T, Zhou H, Yang D, Liu Y, Ma X, Song Z, Nian Q, Feng L, Qin C, Chen L, Tang R (2016) Vaccine engineering with dual-functional mineral shell: a promising strategy to overcome preexisting immunity. Adv Mater 28:694-700

Wang Q, Sun Y, Xu Y, Wang Y, Wang H, Fu Y, Allain JP, Li C, Li T (2019) Seroprevalence of human adenovirus type 5 neutralizing antibody in common marmosets determined by a new set of two assays. Viral Immunol 32:348-354

Wang C, Horby PW, Hayden FG, Gao GF (2020a) A novel coronavirus outbreak of global health concern. Lancet 395:470-473

Wang H, Zhang Y, Huang B, Deng W, Quan Y, Wang W, Xu W, Zhao Y, Li N, Zhang J, Liang H, Bao L, Xu Y, Ding L, Zhou W, Gao H, Liu J, Niu P, Zhao L, Zhen W, Fu H, Yu S, Zhang Z, Xu G, Li C, Lou Z, Xu M, Qin C, Wu G, Gao GF, Tan W, Yang X (2020b) Development of an inactivated vaccine candidate, bbibp-corv, with potent protection against sars-cov-2. Cell 182:713-721

Yu J, Tostanoski LH, Peter L, Mercado NB, McMahan K, Mahrokhian SH, Nkolola JP, Liu J, Li Z, Chandrashekar A, Martinez DR, Loos C, Atyeo C, Fischinger S, Burke JS, Slein MD, Chen Y, Zuiani A, Lelis FJN, Travers M, Habibi S, Pessaint L (2020) DNA vaccine protection against sars-cov-2 in rhesus macaques. Science 369:806-811

Zhu FC, Li YH, Guan XH, Hou LH, Wang WJ, Li JX, Wu SP, Wang BS, Wang Z, Wang L, Jia SY, Jiang HD, Wang L, Jiang T, Hu Y, Gou JB, Xu SB, Xu JJ, Wang XW, Wang W, Chen W (2020a) Safety, tolerability, and immunogenicity of a recombinant adenovirus type- 5 vectored covid-19 vaccine: a dose-escalation, open-label, non-randomised, first-in-human trial. Lancet 395:1845-1854

Zhu FC, Guan XH, Li YH, Huang JY, Jiang T, Hou LH, Li JX, Yang BF, Wang L, Wang WJ, Wu SP, Wang Z, Wu XH, Xu JJ, Zhang Z, Jia SY, Wang BS, Hu Y, Liu JJ, Zhang J, Qian XA, Li Q, Pan HX, Jiang HD, Deng P, Gou JB, Wang XW, Wang XH, Chen W (2020b) Immunogenicity and safety of a recombinant adenovirus type-5-vectored covid-19 vaccine in healthy adults aged 18 years or older: A randomised, double-blind, placebo-controlled, phase 2 trial. Lancet 396:479-488 